\title{
PENDAMPINGAN BAGI FASILITATOR PENDERITA HIPERTENSI DI KABUPATEN KUBU RAYA MELALUI DISEMINASI DIET DASH
}

\author{
Oke Anandika Lestari ${ }^{1}$, Yohana Sutiknyawati Kusuma Dewi ${ }^{1}$, \& Nurmainah ${ }^{2}$ \\ ${ }^{1}$ Prodi Ilmu dan Teknologi Pangan, Universitas Tanjungpura \\ 2Prodi Farmasi, Universitas Tanjungpura \\ oke.anandika@gmail.com; kusumadewiyohana@gmail.com; nurmainah@pharm.untan.ac.id
}

\begin{abstract}
This assistance activity for hypertension facilitator in Kabupaten Kubu Raya through DASH Diet (Dietary Approaches to Stop Hypertension) dissemination is Community Partnership Program (PKM) with it purpose are to increase knowledge and skill of food preparation and food making with DASH Diet approach. The background of this activity is the high number of hypertension patients in Kabupaten Kubu Raya. In DASH Diet approach, consumption of fruit and vegetable or high potassium intake is highly suggested. Partner in this Partnership activity are Community Health Centre (Puskesmas) of Sungai Raya Dalam and PKK (Family Welfare Community) of Kabupaten Kubu Raya. Participant are cadre and delegation from Integrated Service Community (Posyandu) in Kubu Raya. Method used are socialization, training and assistance, and evaluation. DASH Diet is made enriched food with fruit and vegetables, which are cookies with pineapple and low gluten composite noodle enriched with carrot. Participants experienced a very useful assistance supported by comprehension score $62 \%$ for understand, and $32 \%$ very understand. Applied processed food has preferable score 74\% for fruit cookies, and 63\% score for low gluten noodle. Participant are expected to distribute the knowledge and applied it at least in family level. Healthy food application in the future will be developed, not only for it health benefit but also preferable taste.
\end{abstract}

Keywords: Cookies, corn, fruit, potassium, noodle.

\section{PENDAHULUAN}

\section{Analisis Situasi}

Laporan puskesmas di Kalimantan

Barat tahun 2011 menunjukkan kasus hipertensi di Kubu Raya menduduki peringkat ke 2 terbanyak setelah Kabupaten Sambas yaitu 2511 kasus (Uni, 2012). Kubu Raya merupakan Kabupaten di Provinsi Kalimantan Barat yang terdiri dari 9 kecamatan dengan urutan dari wilayah terluas hingga terkecil adalah: Batu Ampar, Kubu, Sungai Raya, Terentang, Sungai Ambawang, Kuala Mandor-B, Sungai Kakap, Telok Pa'kedai, dan Rasau Jaya. Kasus hipertensi di Kabupaten Kubu Raya berdasarkan informasi pegawai puskesmas Kabupaten Kubu Raya adalah terpusat di Sungai Raya Dalam. Oleh sebab itu salah khalayak sasaran da- lam program kemitraan masyarakat ini adalah Puskesmas Sungai Raya Dalam. Khala-yak sasaran lainnya adalah Pembinaan Kesejahteraan Keluarga (PKK) Kabupaten Kubu Raya.

Data sensus tahun 2010 menunjukkan bahwa populasi di Kecamatan Sungai Raya Dalam tertinggi dari 9 kecamatan lainnya, sehingga dapat dikatakan bahwa penduduk Kabupaten Kubu Raya berpusat pada Kecamatan ini. Hal tersebut disebabkan karena wilayahnya yang starategis dan berada dekat dengan kota dan tidak jauh dari pusat keramaian.

Puskesmas Sungai Raya Dalam dibangun tahun 1990 dan saat ini memiliki status akreditasi madya, dan luas bangunan $225 \mathrm{~m}^{2}$ (bangunan bertingkat) dengan 14 
buah ruangan. Tugas pokok Puskesmas dibantu oleh 3 unit Puskesmas pembantu (Parit Baru, Desa Kapur, dan Sei Bulan) dan 4 buah Polindes (Desa Kapur, Sei Bulan, Parit Haji Muksin, dan Mekar Baru). Puskesmas tersebut memiliki struktur organisasi mengacu pada Permenkes No 75 Tahun 2014 yang dikepalai oleh Bapak Suratman, SKM. Total jumlah tenaga kesehatan adalah 48 orang.

Data kasus hipertensi yang diperoleh dari Puskesmas Sungai Raya Dalam dari tahun 2013 hingga 2016 cenderung mengalami peningkatan yaitu dari 1605 kasus menjadi 2083 kasus. Permasalahan yang dihadapi oleh pegawai puskesmas tentang penderita Hipertensi adalah rendahnya kepatuhan meminum obat, dimana penderita mengeluhkan bosan mengkonsumsi obat terus menerus. Menurut Nurmainah dkk., (2013), pengobatan farmakologi bagi penderita hipertensi harus dilakukan terus-menerus sepanjang hidup pasien. Oleh sebab itu diperlukan inovasi baru dengan mengintroduksi makanan yang memiliki potensi menurunkan tekanan darah sehingga penderita yang mengkonsumsi makanan tersebut secara tidak langsung mengkonsumsi obat dalam bentuk lain yang lebih menarik, tidak membosankan, dan tentunya enak. Salah satu cara yang dapat dilakukan adalah dengan mengedukasi dan mengintroduksi Diet DASH (Dietary Approaches to Stop Hypertension). Kendala yang dihadapi untuk penerapan bagi Puskesmas Sungai Raya Dalam adalah 36 terbatasnya tenaga dibidang gizi yaitu hanya 2 orang dan mereka belum mempunyai pengetahuan teknologi pangan khususnya makanan fungsional/kesehatan serta aplikasinya bagi penderita. Kendala lainnya adalah tata kelola introduksi makanan Diet DASH juga belum sepenuhnya dipahami pengaplikasiannya pada makanan olahan.

Informasi lain yang didapatkan dari Dinas Kesehatan Kalimantan Barat bahwa salah satu penyebab tingginya kasus hipertensi adalah pola makanan, dimana salah satu kunci pengatur pola makan adalah ibu sebagai penyedia asupan konsumsi pangan sehari-hari di tingkat rumah tangga. Oleh sebab itu dalam kegiatan PKM ini bekerja sama juga dengan ibu-ibu PKK Kabupaten Kubu Raya.

Permasalahan terkait penderita hipertensi, dimana hampir semua anggota PKK memiliki keluarga yang menderita hipertensi dan bahkan terdapat anggota PKK yang juga sebagai penderita. Kesulitan yang dihadapi oleh PKK diantaranya adalah tingkat pendidikan anggota yang beragam demikian juga ketrampilan dan pengetahuan yang tidak merata khususnya terkait penyakit hipertensi. Anggota PKK pun memiliki masalah hipertensi dalam keluarga/ anggota keluarga PKK yang sama yaitu susahnya mendisiplinkan minum obat bagi anggota PKK sendiri dan atau keluarga yang menderita dengan alasan bosan dengan obat. Oleh sebab itu kegiatan ini sebagai langkah awal menekan tingkat penderita hipertensi di Kabupaten Kubu Raya yang 
memiliki peringkat nomor 2 tertinggi. Pada kesempatan tersebut kegiatan PKM ini pun mendukung program kerja PKK terkait program bidang pendidikan sebagai upaya peningkatan pendidikan dari sisi keterampilan serta kesehatan kelompok PKK juga keluarganya.

Berdasarkan permasalahan kedua mitra tersebut maka kegiatan PKM ini dilakukan dengan sosialisasi, pelatihan dan pendampingan kepada pegawai puskesmas dan ibu-ibu PKK atau yang merupakan kader perwakilan posyandu di Kabupaten Kubu Raya untuk membuat makanan olahan yang menggugah selera makan dan berbahan baku pangan lokal dengan pendekatan Diet DASH. Pendampingan ini dilakukan dengan tujuan untuk meningkatkan wawasan dan ketrampilan pengolahan pangan dengan pendekatan Diet DASH. Target utama dalam kegiatan ini adalah penerapan olahan pangan minimal $70 \%$ peserta ditingkat keluarga.

\section{Kajian Literatur}

Diet DASH merupakan makanan yang dapat membantu menurunkan tekanan darah, yaitu makanan yang kaya akan kalium, magnesium, kalsium, dan serat pangan. Menurut Rahadiyanti dkk., (2015) hasil studi Diet DASH menunjukkan diet dengan tinggi sayur, buah, dan hasil olahan susu rendah lemak (lemak jenuh dan total), serta tinggi kandungan kalium, kalsium, dan magnesium dapat menurunkan tekanan darah sistolik 6-11mmHg dan tekanan diastolik 3-6mmHg. Studi khort juga menunjukkan bahwa Diet DASH berhubungan dengan tingginya kejadian hipertensi terutama bagi wanita (Krummel dkk., 2004). Tekanan darah melebihi dari 120/80mmHG menunjukkan beresiko hipertensi. Makanan yang memberikan pengaruh penurunan tekanan darah telah diteliti adalah pisang (Dayand dkk., 2015), nanas (Hossain dkk., 2016), jagung (George dkk., 2013), dan pepaya (Eno dkk., 2000).

Tabel 1. Jumlah produksi pangan lokal berpotensi turunkan tekanan darah di Kabupaten Kubu Raya tahun 2015.

\begin{tabular}{llr}
\hline No & Komoditi & Produksi (Ton) \\
\hline 1. & Pisang & $30.767,3$ \\
\hline 2. & Jagung & $8.048,0$ \\
\hline 3. & Pepaya & $1.425,6$ \\
\hline 4. & Nanas & 115,6 \\
\hline
\end{tabular}

Sumber: BPS, 2015

Bahan baku makanan yang memiliki efek menurunkan tekanan darah adalah makanan yang kaya akan kandungan kalium. Menurut Ston dkk., (2016) konsumsi kalium dapat menurunkan tekanan darah, dimana kalium banyak terkandung dalam buah dan sayuran. Rekomendasi konsumsi kalsium yang dikeluarkan oleh Food and Nutrition Board Innstitute of Medicine adalah $4700 \mathrm{mg} / \mathrm{hari}$ (Appel dkk, 2006). Bahan pangan lokal di Kabupaten Kubu Raya populer dan ternyata berpotensi menurunkan tekanan darah ditampilkan pada Tabel 1. Bahan pangan lokal tersebut akan diberikan sentuhan teknologi menjadi bentuk yang lebih praktis yaitu cookies dan mi jagung. 
Upaya menurunkan tekanan darah tidak hanya dilakukan dengan meningkatkan konsumsi kalium, akan tetapi dengan menjaga berat badan berat badan tetap idel $\left(<25 \mathrm{~kg} / \mathrm{m}^{2}\right)$, menurunkan konsumsi garam (idealnya 1,5g/hari), konsumsi sayur dan buah (8-10 porsi/hari), dan hindari konsumsi alkohol (Appel dkk, 2006).

\section{METODE PELAKSANAAN}

Pelaksanaan kegiatan ini dilakukan di Puskesmas Sungai Raya Dalam dan kantor sekretariat PKK Kabupaten Kubu Raya. Khalayak sasaran kegiatan PKM ini adalah fasilitator bagi penderita hipertensi yang merupakan kader dari perwakilan Posyandu di Kabupaten Kubu Raya dan Perwakilan Puskesmas Sungai Raya Dalam yang menangani bagian gizi.

Bahan baku utama yang digunakan dalam pembuatan cookies adalah tepung terigu dan nanas, sedangkan mi menggunakan tepung komposit antara tepung terigu dengan tepung jagung, dan tepung singkong, serta diperkaya wortel. Alat yang digunakan adalah mixer, oven, cetakan, pencetak mi, dan pendukung pengolahan lainnya.

Metode pelaksanaan yang dilakukan adalah dengan beberapa tahapan, yaitu:

1. Sosialisasi materi dengan ceramah dan diskusi dengan khalayak sasaran mengenai penyakit hipertensi dan Diet DASH;
2. Pelatihan dan pendampingan pengolahan cookies dan mi;

3. Evaluasi kegiatan dilakukan untuk mengetahui tingkat penerimaan kegiatan PKM yang telah dilakukan.

\section{HASIL DAN PEMBAHASAN}

\section{Sosialisasi dengan Ceramah dan Diskusi}

Materi yang diberikan berupa penguatan terkait penyakit hipertensi dan Diet DASH. Pemateri dalam kegiatan dari Puskesmas Sungai Raya Dalam, yaitu Dr Diska Astarini dan Suyanti ST Gz. Kegiatan ini disampaikan dalam bentuk ceramah dan diskusi. Peserta yang hadir memiliki keberagaman usia yang didominasi pada kisaran 36 tahun hingga 45 tahun (Gambar 1). Latar belakang peserta separuh bagian adalah ibu rumah tangga sebagai penderita hipertensi atau memiliki anggota keluarga atau kenalan penderita, sedangkan sisanya adalah kader dari posyandu Kabupaten Kubu Raya.

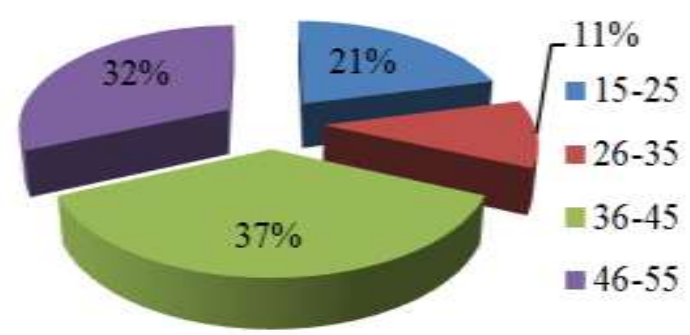

Gambar 1. Karakteristik usia peserta (tahun).

$$
\text { Penguatan terkait penyakit }
$$
hipertensi yang disampaikan oleh Dr Diska (Gambar 2). Materi tentang penyakit diutamakan adalah menyampaikan tentang 
penertian umum, penyebab dan gejalanya, serta cara mengindari. Selain itu dikatakan pula bahwa pengobatan bagi penderita hipertensi tidak hanya dapat dilakukan dengan cara farmakologi (konsumsi obat) akan tetapi juga dapat secara nonfarmakologi yaitu dengan mengatur pola makan.

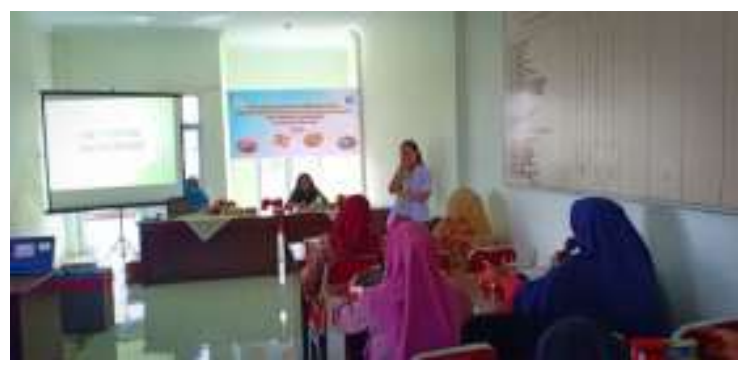

Gambar 2. Penyampaian materi penyakit hipertensi oleh Dr Diska.

Materi tentang pola makan untuk penderita hipertensi di sampaikan oleh Suyanti ST Gz. Kabupaten Kubu Raya disampaikan oleh Suyanti sudah mendeteksi anak remaja usia di bawah 20 tahun yang diduga menederita prehipertensi. Oleh sebab itu keluarga harus menciptakan kebiasaan untuk mencegah penyakit tersebut, salah satu caranya adalah membiasakan konsumsi sayur dan buah. Hal tersebut juga dapat mendukung program pemerintah untuk meningkatkan konsumsi sayur dan buah pada anak-anak.

Perwujudan dukungan untuk menurunkan penderita hipertensi dan meningkatkan konsumsi sayur dan buah pada anak sekaligus upaya mencegah adanya penderita hipertensi diusia remaja, maka tim PKM memberikan teknologi pangan olahan yang diperkaya sayur dan buah (Gambar 3). Tujuan dari mengolah makanan ini adalah untuk menurunkan kejenuhan dalam mengkonsumsi sayur dan buah, selain itu juga untuk meningkatkan minat anak. Harapannya dengan memberikan sayur dan buah dalam bentuk lain (olahan pangan) akan meningkatkan minat anak untuk mengkonsumsinya.

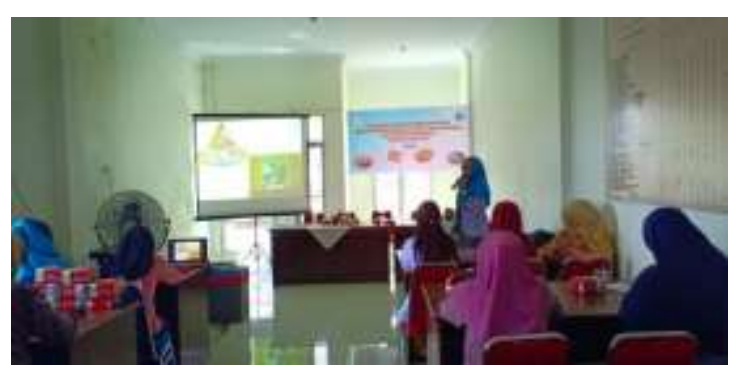

Gambar 3. Penyampaian materi teknologi olahan pangan.

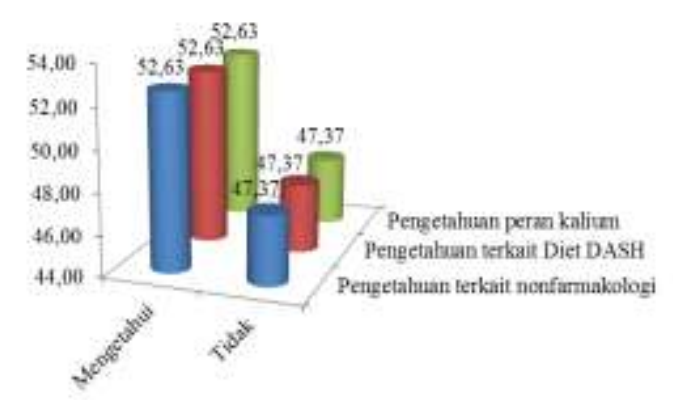

Gambar 4. Pengetahuan terkait materi sebelum kegiatan sosialisasi.

Kegiatan sosialisasi ini dapat meningkatkan atau memperkuat pengetahuan peserta terutama terkait pengobatan nonfarmakologi, tentang diet DASH, dan peran kalium untuk penderita hipertensi. Hal tersebut ditunjukkan dengan Gambar 4, bahwa $47,37 \%$ peserta sebelumnya tidak mengetahui tentang pengetahuan tersebut. Hampir separuh peserta belum mengetahui pengatahuan yang diberikan karena 
separuh peserta merupakan ibu rumah tangga yang mungkin belum pernah mendengar terkait materi yang diberikan, akan tetapi dengan kegiatan sosialisasi ini dapat memberikan pengetahuan baru kepada peserta tersebut.

\section{Pelatihan dan Pendampingan}

Pelatihan yang dilakukan terdapat dua kegiatan berupa pengolahan cookies dengan buah nanas dan pengolahan $\mathrm{mi}$ rendah gluten dari tepung komposit tepung terigu dengan tepung jagung yang diperkaya wortel. Alasan pemilihan jenis pangan tersebut untuk diterapkan adalah karena dapat diterima semua kalangan baik usia muda maupun tua, terutama mi yang merupakan salah satu makanan populer di Indonesia.

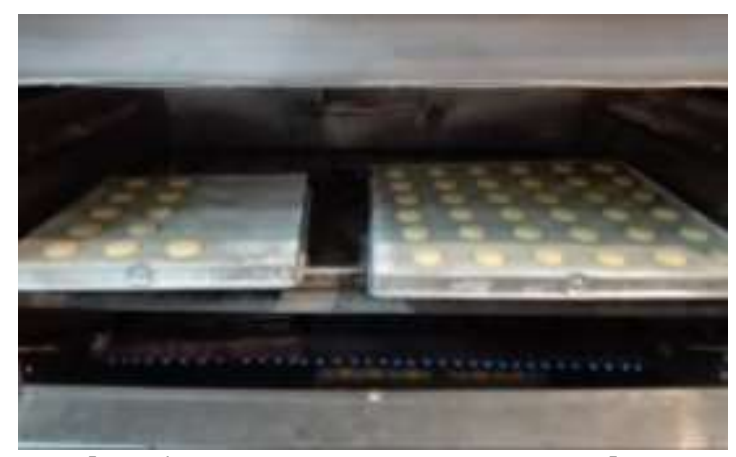

Gambar 5. Proses pemanggangan cookies buah nanas.

Pengolahan cookies dilakukan dengan metode all in atau mencapur seluruh bahan yang digunakan menjadi satu dengan mixer kemudian dicetak dan dipanggang (Gambar 5). Formulasi bahan dan tahapan proses dilakukan menurut Lestari dkk (2018), yaitu dengan mensubstitusi $45 \%$ tepung terigu dengan puree nanas, serta menggunakan gula dengan konsentrasi 20\% dari berat tepung. Komposisi kandungan buah nanas pada total formulasi bahan baku yang digunakan adalah $22 \%$, sehingga dengan mengkonsumsi $100 \mathrm{~g}$ cookies telah memenuhi anjuran konsumsi buah sebanyak 14,67\%. Menurut Badan Kesehatan Dunia atau WHO konsumsi sayuran dan buah yang dianjurkan adalah 400g yang terdiri dari 250g sayuran dan 150g buah (Biro Komunikasi dan Pelayanan Masyarakat, 2017). Kandungan kalium yang terdapat dalam $70 \mathrm{~g}$ cookies adalah 155.56mg. Pemenuhan konsumsi kalium yang terpenuhi sekitar $3,3 \%$ dari $4700 \mathrm{mg} /$ hari yang dianjurkan.

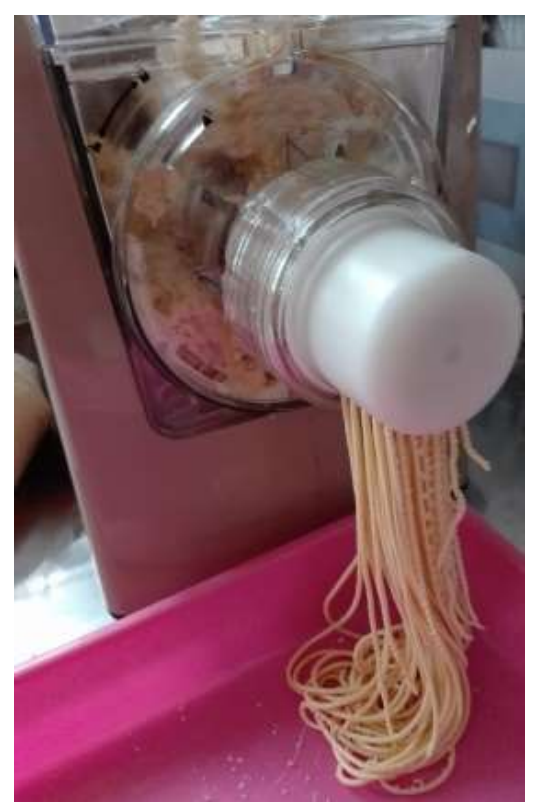

Gambar 6. Proses pengolahan mi.

Pengolahan mi menggunakan
campuran tepung jagung yang
menggantikan tepung terigu sebanyak $20 \%$ 
dan sari wortel (perbandingan air:wortel 1:2 b/b) 30\% dari berat tepung. Pengolahan mi tersebut merupakan modifikasi dari Lestari dkk (2009), akan tetapi perbedaannya adalah alat yang digunakan yaitu alat pembuat mi otomatis atau noodle maker (Gambar 6) dan penyesuaian formulasi. Mi dapat diolah lebih lanjut dengan berbagai cara menjadi produk seperti mi basah, mi kering (di keringkan menggunakan oven), dan mi keremes (di goreng dengan minyak). Pengolahan tersebut dapat disesuikan tergantung keperluan.

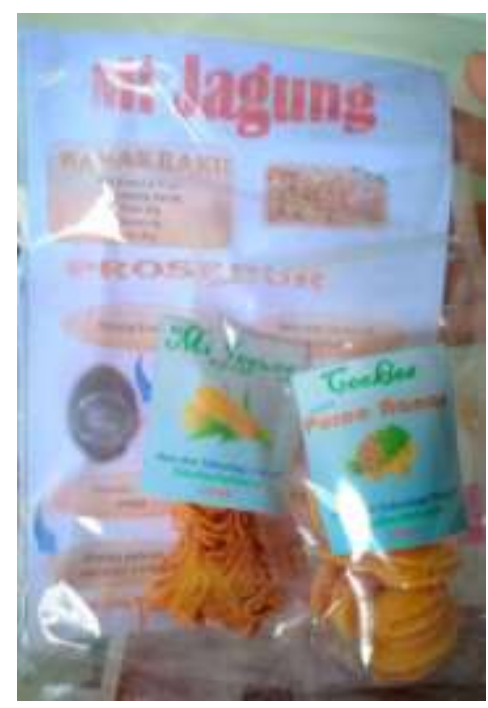

Gambar 7. Hasil penerapan teknologi olahan buah dan sayur.

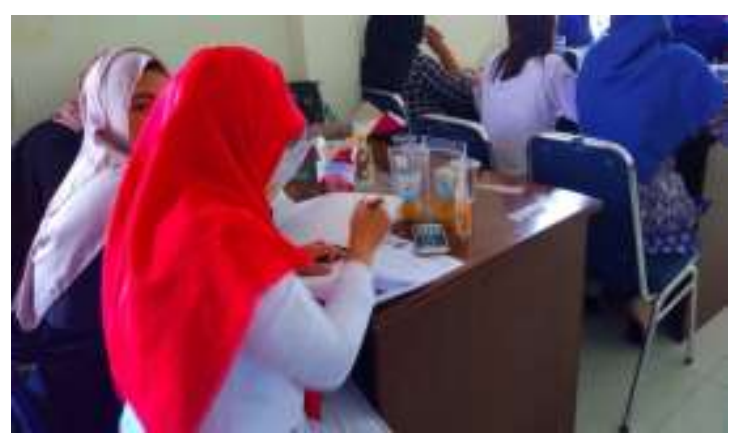

Gambar 8. Pengisian kuisioner tingkat kesukaan produk.
Produk yang dihasilkan dikemas dengan kemasan klip (Gambar 7), sehingga dapat meminimalisasi kontak dengan udara dan produk tidak mudah menurun tingkat kerenyahannya. Selain itu dengan adanya klip juga memudah dalam membu dan menutup kemasan.

Kegiatan pengukuran tingkat kesukaan produk yang dihasilkan dilakukan dengan menggunakan kuisioner (Gambar 8). Hasil penilaian tingkat kesukaan peserta terhadap produk yang dihasilkan ditampilkan pada Gambar 9. Produk cookies didominasi dengan tingkat kesukaan sangat suka sebesar $73,68 \%$, sedangkan mie suka sebesar 63,16\%. Berdasarkan hal tersebut dapat dikatakan bahwa peserta menilai tingkat kesukaan pada cookies yang lebih tinggi dibandingkan mi. Pengukuran tersebut dilakukan dengan mengaplikasikan mi menjadi mi keremes (Gambar 7).

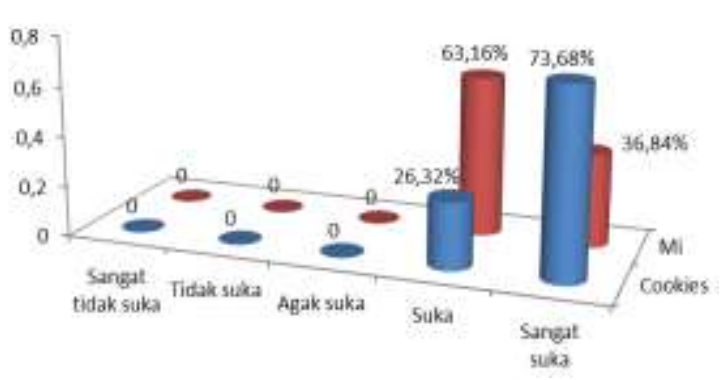

Gambar 9. Tingkat kesukaan kroduk.

Hal tersebut diduga menjadi penyebabnya karena mi dibuat tanpa menggunakan atau penambahan bumbu sehingga terasa tawar. Pengaplikasian mi menjadi mi keremes kedepannya dapat dikembangkan dengan memberikan 
tambahan bumbu. Penggunaan bumbu pun berpotensi untuk membantu dalam menurunkan tekanan darah. Hasil penelitian beberapa jenis tergolong bumbu yang dapat menurunkan tekanan darah adalah bawang putih (Noviantri, 2009), lada hitam (Ernawati, 2005), dan ketumbar (Romlah, 2015).

\section{Evaluasi}

Evaluasi dilakukan untuk mengetahui tingkat kegunaan kegiatan menurut peserta dan penerapan serta aplikasi hasil kegiatan yang telah dilakukan. Data diperoleh dengan memberikan kuisioner kepada peserta. Hasil data evaluasi kegiatan ditampilkan pada Gambar 10 hingga 12.

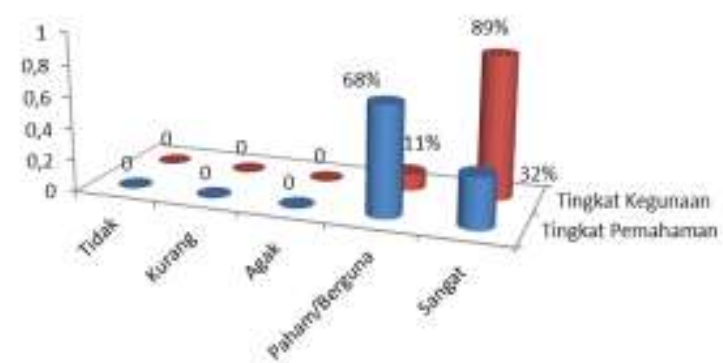

Gambar 10. Tingkat pemahaman dan kegunaan kegiatan.

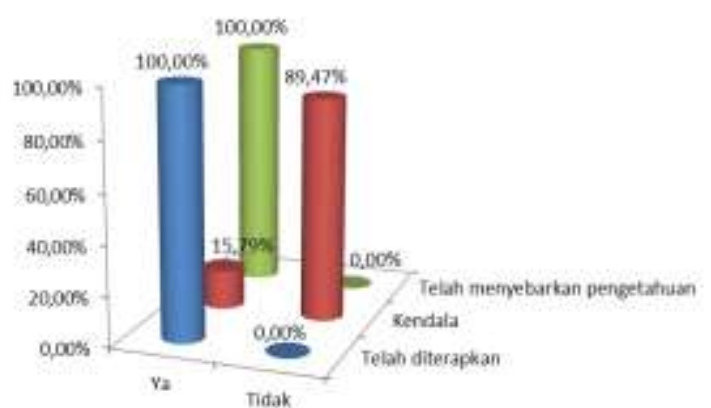

Gambar 11. Tingkat penerapan kegiatan.
Evaluasi kegiatan berdasarkan tingkat pemahaman dan kegunan dari kegiatan yang diberikan didominasi dengan $68 \%$ peserta paham terhadap kegiatan yang diberikan dan 89\% mengatakan bahwa kegiatan yang diberikan sangat berguna (Gambar 10). Hasil tersebut menunjukkan bahwa metode sosialisasi dengan menggunakan slide dan brosur dapat membantu.

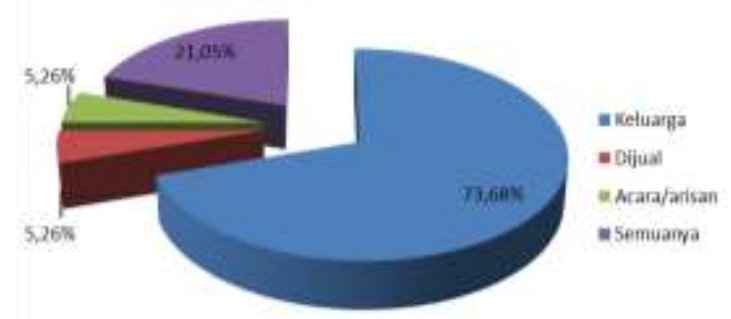

Gambar 12. Tempat penerapan olahan.

Tingkat penerapan menunjukkan bahwa seluruh peserta telah menerapkan atau membuat olahan pangan yang diberikan dan telah menyebarkan informasi yang telah diperoleh dari kegiatan PKM ini (Gambar 11). Hampir seluruh peserta tidak memiliki kendala untuk menerapkan atau mengaplikasikan olahan pangan yang diberikan. Peserta yang memiliki kendala dalam menerapkan olahan pangan yang diberikan ada sebanyak 15,79\%. Wawancara lebih lanjut disebabkan karena kesulitan untuk menghasilkan cookies yang matang tetapi memiliki warna yang bagus tidak gosong. Oleh sebab itu diberikan informasi kembali bahwa proses pemanggangan harus menggunakan api yang sangat kecil (Gambar 5), sehingga cookies matang sempurna. 
Penerapan olahan yang telah diberikan telah diterapkan atau dicoba oleh seluruh peserta (Gambar 12). Persentase tertinggi yaitu 73,68\% penerapan dilakukan di tingkat keluarga (Gambar 10). Hasil tersebut sesuai dengan target kegiatan bahwa minimal penerapan telah dilakukan di tinggat keluarga sebesar $70 \%$ dari peserta.

\section{KESIMPULAN DAN SARAN}

\section{Kesimpulan}

Pengolahan sayur dan buah menjadi cookies dan mi berpotensi dikembangkan sebagai upaya meningkatkan konsumsi sayur dan buah, serta meningkatkan asupan kalium untuk penderita hipertensi. Tingkat kesukaan yang tinggi dari produk tersebut merupakan pendukung utama pengaplikasian. Peningkatan pengetahuan terkait pengolahan produk pun dapat tercapai yang ditunjukkan dengan 100\% peserta telah menerapkannya dan dilakukan di tingkat keluarga sebanyak 73,68\%.

\section{Saran}

Saran untuk pengolahan mi keremes dapat dilakukan modifikasi formulasi dengan menambahkan bumbu sehingga dapat meningkatkan lagi kesukaan terhadap produk.

\section{UCAPAN TERIMA KASIH}

Penulis ucapkan terimakasih kepada KEMENRISTEK DIKTI melalui Anggaran tahun 2018 yang telah membiayai kegiatan ini dengan Program Kemitraan Masyarakat (PKM) dan LPPKM UNTAN. Terimaksih dan pasrtisipasi juga diucapkan kepada mitra kegiatan yaitu pimpinan dan staff di Puskesmas Sungai Raya Dalam, pengurus dan anggota PKK Kabupaten Kubu Raya, serta peserta kegiatan. Ucapan khusus juga diberikan kepada seluruh mahasiswa yang terlibat.

\section{KEPUSTAKAAN}

Appel L J, Brands M W, Daniels S R, Karanja N, Elmer P J, dan Sacks F M. 2006. Dietary Approaches to Prevent and Treat Hypertension A Scientific From the American Hart Association. AHA Scientific Statement. 47:296-308.

Biro Komunikasi dan Pelayanan Masyarakat. 2017. Hari Gizi Nasional 2017: Ayo Makan Sayur dan Buah setiap Hari. Diakses pada tanggal 5 Maret 2018.

http://www.depkes.go.id/article/print/ 17012600002/hari-gizi-nasional-2017ayo-makan-sayur-dan-buah-setiaphari.html.

BPS. 2015. Kalimantan Barat dalam Angka 2015. Badan Pusat Statistik Provinsi Kalimantan Barat. Pontianak.

Dayand, G., Sharma, A., Ahmed, M., Jyothi, PP., dan Rani, M. 2015. Effect of Banana on Blood Pressure of Hypertensive Individuals: a Cross Sectional Study From Pokhara, Nepal. Medical Science 3(2):233-237.

Eno, A E., Owo, O I., Itam, E H., Konya, R S. 2000. Blood pressure depression by the fruit juice of Carica papaya (L.) in Renal and DOCA-induced Hypertension in the Rat. NCBI. 14(4):235-239.

Ernawati D. 2005. Efek Farmakologi Suspensi Biji Lada Hitam (Piper nigrum L.) dan Piperin terhadap Tekanan Darah Kucing Teranestesi. Diakses tanggal 3 Juni

2018. 
file://C:/Users/USER/Downloads/418 -508-2-PB.pdf.

George, G O., Idu, F K., Obika, L F O. 2013. Effect of Corn Silk Aqueous Extract on Intraocular Pressure of Ocular Hypertensive Human Subjects. The South African Optometrist 72(3):133143.

Hossain, F., Akhtar, S., dan Anwar, M. 2015. Nutritional Value and Medicinal Benefits of Pineapple. International Journal of Nutrition and Food Sciences, 4(1):84-88.

Krummel, D A. Medical Nutrition Therapy ini Hipertension, and Diet Therapy Chapter 36. Saunders Elsevier. Canada.

Lestari, O A. 2009. Karakteristik Sifat FisikoKimia dan Evaluasi Nilai Gizi Biologis Mi Jagung Kering yang Disubstitusi Tepung Jagung Termodifikasi. Tesis. IPB. Bogor.

Lestari O A, Dewi Y S K, dan Nurmainah. 2018. Karakteristik Sensori Cookies Kaya Kalium Hasil Substitusi Tepung Terigu Dengan Puree Nanas Bagi Penderita Pre-Hipertensi. Seminar PIPT IV Tahun 2018. Universitas Tanjungpura. Pontianak.

Noviantari D. 2009. Pengaruh Konsumsi Bawang Putih terhadap Penurunan Tekanan Darah pada Penderita Hipertensi di Desa Demangrejo, Sentolo, Kulon Progo, Yogyakarta Tahun 2009. Skripsi. Sekolah Tinggi Ilmu Kesehatan 'Aisyyah. Yogyakarta.

Nurmainah, Fudholi A, dan Dwiprahasto I. 2013. Persistensi Penggunaan Obat
Antihipertensi pada Pasien Hipertensi Rawat Jalan. Jurnal Kesehatan Masyarakat Nasional. 8(1):13-18.

Permenkes. 2014. Peraturan Menteri Kesehatan Republik Indonesia Nomor 75 Tahun 2014 tentang Pusat Kesehatan Masyarakat. Menteri Kesehatan. Jakarta. Diakses tanggal 6 Juni 2017. http://www.aidsindonesia.or.id/upload s/20141210110659.PMK No 75 Th 20 $14 \mathrm{ttg}$ Puskesmas.pdf.

Rahadiyanti, A., Setianto, B, Y., Purba, M B. 2015. Asupan makanan DASH-like diet untuk mencegah resiko hipertensi pada wanita prediabetes. Jurnal Gizi Klinik Indonesia. 11(3):115-125.

Romlah S. 2015. Pengaruh Rebusan Biji Ketumbar sebagai Penurun Hipertensi pada Ibu Hamil di Desa Jabon Kecamatan Mojoanyar Mojokerto. Laporan Penelitian. Diakses tanggal 3 Juni 2018. http://repository.poltekkesmajapahit.ac .id/index.php/PUBKEB/article/viewFile/444/358.

Stone, M S., Martyn, L., Weaver, C M. 2016. Potassium Intake, Bioavailability, Hypertension, and Glucose Control. Nutrients Review 8, 444.

Uni. 2012. Hipertensi dan Hipertensi Melitus, Penyakit Terbanyak di Kalbar. Diakses pada tanggal 6 Juni 2017. http://www.jpnn.com/news/hipertensi -dan-hipertensi-mellitus-penyakitterbanyak-di-kalbar. 